\title{
Kan pasienttekster ha medisinsk relevans?
}

\author{
Innenfor humanistisk helse- og sykdomsforskning anses litterære tekster som en kilde til innsikt omkring \\ sykdom og helse. Vekten har ligget hos pasienten som tekst, sykdom som litteratur eller legen som litterær \\ skikkelse. Men hva når pasienten skildrer egen sykdomshistorie? Kan litteraturvitenskapelige, sosiologiske \\ og medisinske perspektiver sammen bidra til økt forståelse av pasienttekster som medisinsk relevante? \\ Bør den involverte pasientens egen sykdomsfortelling på sikt inkluderes i journalen?
}

\section{Linda H. Nesby}

linda.nesby@uit.no

Anita Salamonsen

Humanistisk helse- og sykdomsforskning er i sitt møte mellom humaniora og medisin tverrfaglig av natur. Litterære tekster anses som en kilde til innsikt i oppfatninger av sykdom og helse (1). Utgangspunktet har vært pasienten som tekst $(2,3)$, sykdom som litteratur $(4,5)$, legen som litterær skikkelse $(6,7)$ eller legen som forteller $(8,9)$. Det litteraturvitenskapelige har bestått $\mathrm{i}$ å supplere beskrivelser og forståelser av sykdom og helse innenfor det medisinske feltet.

Et norsk pionerarbeid er Petter Aaslestads Pasienten som tekst fra 1997 (2). Den omhandler fortellerrollen i psykiatriske journaler ved Gaustad psykiatriske klinikk mellom 1890 og 1990. Pasienten som tekst representerte noe nytt innenfor norsk forskning på narrativitet og medisin med vektleggingen av hvordan journalsjangeren utvikler seg og i forsøket på å formulere sjangerens grunnleggende fremstillingsformer ved hjelp av litteraturvitenskapelig teori.

I Hilde Bondevik \& Knut Stene-Johansens Sykdom som litteratur settes søkelyset på hvordan noen av vår tids mest kjente sykdommer fremstilles litterært (4). De skjønnlitterære tekstene behandles som kunstnerisk bearbeiding av en medisinsk erfaring - eller som en skjønnlitterær foregripen av medisinsk innsikt. Det vesentlige er å avdekke hvordan sykdomserfaringens språk arter seg.

At leger og forfattere skriver om sykdom, er ikke overraskende. Man trenger imidlertid ikke å være lege eller forfatter for å skrive om dette. I samfunn som de moderne vestlige, hvor skrift og tekstproduksjon har stor plass, lar stadig flere lekfolk sin egen sykdom danne utgangspunkt for skrivevirksomhet. Vi argumenterer i denne kronikken for viktigheten av at pasientperspektivet inkluderes i journalen og for betydningen av et fremtidig tverrfaglig perspektiv på pasienters tekster om egne sykdomsopplevelser.

\section{Fra tekst til tekstprodusent}

Skriftlig fremstilling av egen sykdom er siden år 2000 blitt stadig mer vanlig. Sjangeren kalles patografi og var opprinnelig reservert fremstillingen av kjente menneskers sykdomsforløp (8). I boken Reconstructing illness. Studies in pathographies lar imidlertid Anne Hunsaker Hawkins patografien også inkludere alle typer personlige sykdomsfortellinger (9). Termen «autopatografi» brukes når den syke selv skriver om sin sykdomserfaring. Større forskningsarbeider der man gjør bruk av begrepet «autopatografi» $(10,11)$ illustrerer den økte interessen for pasienters egen sykdomsfremstilling: Pasienten har gått fra å være tekst til selv å bli tekstprodusent.

\section{En handlende aktør}

\section{i forhold til sin egen sykdom}

I et sosiologisk perspektiv er dette i tråd med den reverseringen av det tradisjonelle helsehierarkiet - med helsearbeidere som den aktive part og pasienten som den passive som vi gjenfinner både i norske pasienters praksis og i de senere års helsepolitiske styringsdokumenter som stortingsmeldingene Samhandlingsreformen og Morgendagens omsorg $(12,13)$. Begrepene «sykdom» og «sykdomsopplevelse» inkluderer i et slikt perspektiv fortolkning, beslutninger og handling og beskrives ofte som "pasientperspektivet». Pasientene er handlende subjekter i eget liv, for eksempel i møte med sykdom og det offentlige helsevesenet.

Epistemologisk sett inkluderer kunnskap om pasientens sykdom her også pasientens erfaringsbaserte kunnskap, som er kontekstuelt påvirket og sosialt konstruert $(14,15)$ og som vi gjenfinner i pasientenes egne skriftlige beretninger om hvordan de forstår sin sykdom og tenker rundt behandlingen av den. Mange sosiologiske studier, for eksempel arbeidene til Arthur W. Frank (16), har vist at pasienter i sine sykdomsfortellinger vektlegger andre aspekter ved behandlingen enn overlevelse og helbredelse, for eksempel livskvalitet samt mening og mestring av det nye livet med sykdommen.

\section{Medisinske initiativer}

At mange pasienter skriver om egen sykdomsopplevelse, er sikkert kjent for de fleste leger. Det finnes også eksempler på at leger aktivt har oppfordret pasientene til å ta pennen fatt. I 2003 disputerte Per Steinsland på en avhandling knyttet til samtaler ved fastlåste kroppslige plager, basert på pasienters egne dagboknotater (17). Steinsland ba et utvalg av sine pasienter om å skrive helsedagbøker. Disse dannet grunnlaget for konsultasjonen mellom lege og pasient.

I 2004 lanserte de britiske samfunnsmedisinerne Macnaughton \& Evans tanken om at både pasient og lege kunne skrive i journalen (18). De beskriver den ideelle journal som en sjangerhybrid med ulike forfattere og dermed ulike narrative teknikker og fremstillingsformer: «The clinical record ought to have two parallel parts, of which one would be written in the first person by the patient or in the third person by a specific representative of that patient.» Artikkelforfatterne etterspør et samarbeid mellom feltet medisinsk humaniora og medisinsk informatikk for å utarbeide et system som gjør dette praktisk mulig.

I 2005 grep de norske medisinerne Jan Frich \& Per Fugelli tak i dette initiativet (19). I likhet med sine britiske kolleger vektlegger Frich \& Fugelli at stadig flere pasienter ønsker å bli betraktet som likeverdige i sine møter med helsevesenet og som aktive aktører når det gjelder sykdom og sykdomsbehandling. De erkjenner de praktiske utfordringene ved denne type samskrevet journal, men anbefaler likevel en utredning. I boken Journalen fra 2013 fremholder Fugelli verdien av å åpne journalene for pasientens egne notater (20). Pasienten vil ha godt av å bli hørt, og legen vil kunne få innblikk i aspekter rundt sykdomsopplevelsen som kan ha medisinsk relevans: » [...] pasientenes rett til å skrive 


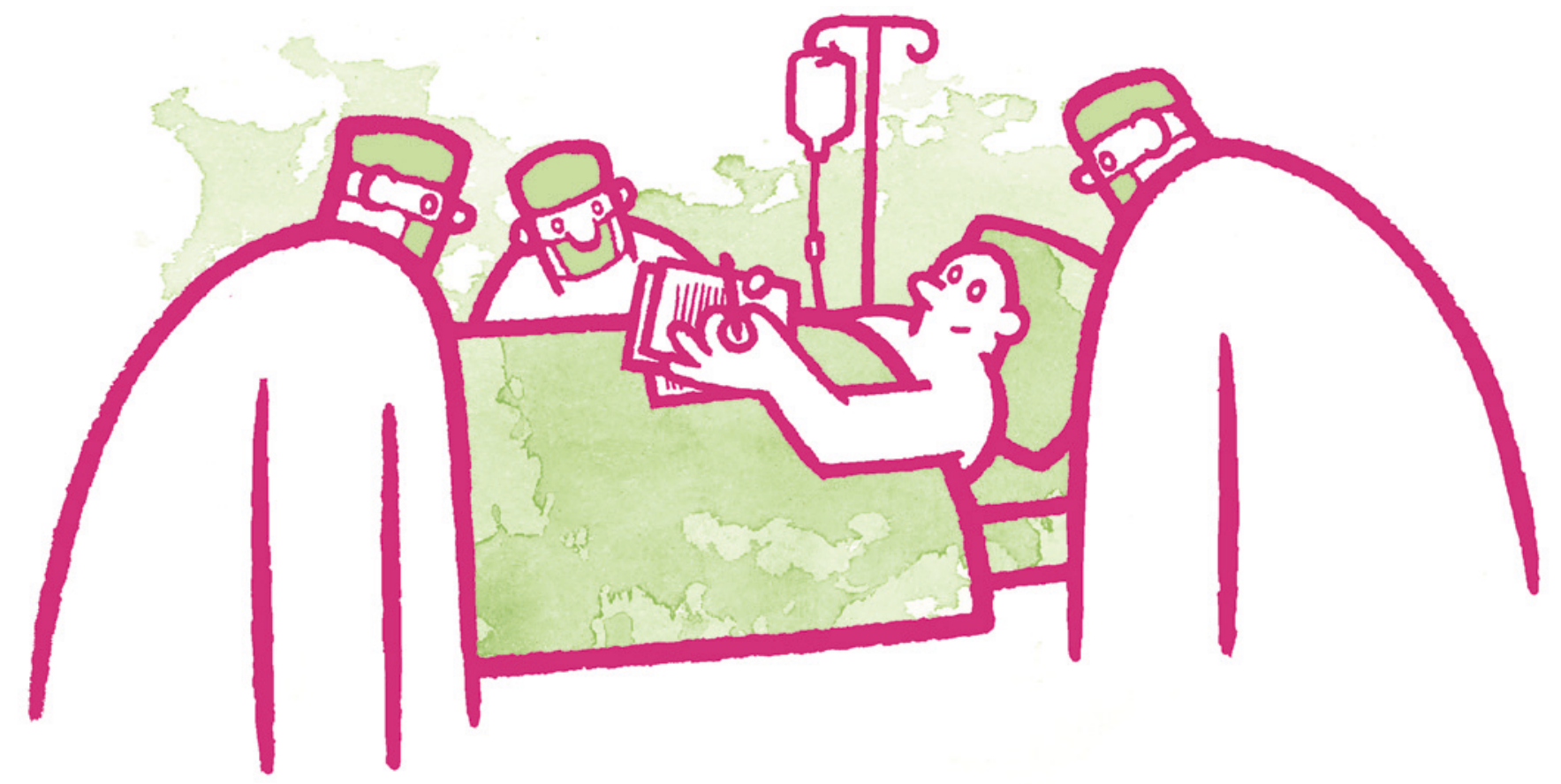

Illustrasjon (c) Superpop

om egen sykdomsopplevelse er et ledd i demokratiseringen av forholdet mellom helsetjenesten og befolkningen [...]. Helsepersonell-loven bør få en ny paragraf som gir legene plikt til innsyn i pasientens journal» (20).

\section{Muligheter og utfordringer}

Utgangspunktet i en autopatografi er at pasienten er førstepersonsforteller i beretningen om sin egen sykdomsopplevelse. I eventuelle førstegangsforsøk på å implementere pasienttekster i medisinsk journal kan en tverrfaglig forståelse av fortellertekniske elementer hentet fra litteraturvitenskapen sammenholdt med sosiologiske og medisinske forståelser av sykdomsopplevelser og sykdomsforløp være viktig.

Oppblomstringen av autopatografier har skjedd parallelt med fremveksten av skjønnlitterære selvfremstillinger slik vi blant annet finner det hos Claus BeckNielsen og Karl-Ove Knausgård $(21,22)$. Innenfor litteraturvitenskapen er det fornyet teoretisk og metodisk interesse for bruken av biografisk materiale i litteraturen. Begrepet «performativ biografisme» brukes for eksempel når biografiske opplysninger opptrer som estetisk virkemiddel i teksten.

Men hva når autopatografiene benytter kunstprosa som virkemiddel i en biografisk tekst? Hvordan behandler man en tekst som ikke er kronologisk organisert, og hvilke implikasjoner gir det dersom pasientens egen sykdomsfremstilling er preget av henholdsvis oppsummering, detaljerte scener eller store tekstlige sprang? Hvilke hendelser velger fortelleren å ta med, og hvilke utelates? Og hvordan fremstiller fortelleren seg selv og helsearbeiderne? Slike basale litteraturvitenskapelige spørsmål bør stilles autopatografiene $\mathrm{i}$ et forsøk på å nå frem til en mest mulig komplett forståelse av pasientens egne tanker og følelser omkring sin egen sykdom.

Sosiologiske analyser av pasientenes tekster kan bidra til økt forståelse av pasientperspektivet, som for eksempel pasienters sykdomsforståelse og behandlingsmål. Sosiologien kan også bidra med $ø k t$ innsikt i relasjonen mellom pasient og helsearbeider/behandlingssystem. Bidrag fra både litteraturvitenskapen og sosiologien kan slik være med på å synliggjøre pasientteksters relevans i en eventuell implementering av slike tekster i journalen og i neste omgang i behandlingen av «morgendagens involverte pasient».

Selvsagt vil en slik tverrfaglig fortolkning av pasienttekster være ressurskrevende. Vi mener imidlertid at dette kun behøver å være nødvendig i en implementeringsfase, der tverrfaglige team kan utvikle verktøy som leger senere kan anvende i sin kliniske praksis. Helsemyndighetenes vektlegging av den involverte pasienten, endringer i medisinstudiene for eksempel i Tromsø og moderne pasienter som er aktive i kliniske møter er allerede i ferd med å endre pasientens posisjon når det gjelder deltakelse i sin egen behandling.

\section{Veien videre}

Pasientens egen tekst kan være en unik kilde til kunnskap om sykdomsopplevelse og vedkommendes møte med helsevesenet. Måten fortelleren skildrer sine helseproblemer på, har viktige subjektive og kontekstavhengige elementer som kan tenkes å komplettere en tradisjonell medisinsk forståelse av pasientens sykdom og behandlingsbehov. Utviklingen har vist at stadig flere pasienter produserer fortellinger om sine egne sykdomsopplevelser. Det er ikke urimelig å tenke seg at tekstene kan ha medisinsk relevans og inngå i journalen.

Mer forskning på pasienttekster og eventuelle forsøk på å implementere disse i grunnlaget for klinisk praksis vil være et signal om at man tar denne type tekster alvorlig, både som litterære ytringer og som kvalifiserte uttalelser om sykdom og medisinsk praksis. En debatt om pasientperspektivets relevans i journalen er viktig $i$ en tid der pasientinvolvering står sentralt i norske helsemyndigheters styringsdokumenter og «den involverte pasienten» i økende grad skal være et bærende prinsipp i medisinsk praksis.

\section{Linda H. Nesby (f. 1972)}

er litteraturviter og førsteamanuensis i nordisk språk og litteratur ved Institutt for kultur og litteratur, Fakultet for humaniora, samfunnsvitenskap og lærerutdanning, Universitetet i Troms $\varnothing$ - Norges arktiske universitet.

Forfatter har fylt ut ICMJE-skjemaet og oppgir ingen interessekonflikter. 


\section{Anita Salamonsen (f. 1963)}

er sosiolog og seniorforsker ved Nasjonalt forskningssenter innen komplementær og alternativ medisin, Institutt for samfunnsmedisin, Det helsevitenskapelige fakultet, Universitetet i Troms $\varnothing$ - Norges arktiske universitet. Forfatter har fylt ut ICMJE-skjemaet og oppgir ingen interessekonflikter.

\section{Litteratur}

1. Frich JC. Medisin som litterær virksomhet. Tidsskr Nor Lægeforen 2003; 123: 2474-6.

2. Aaslestad P. Pasienten som tekst: fortellerollen i psykiatriske journaler. Gaustad 1890-1990. Oslo: Tano Aschehoug, 1997.

3. Daniel SL. The patient as text: a model of clinical hermeneutics. Theor Med 1986; 7: 195-210.

4. Bondevik H. Stene-Johansen K. Sykdom som litteratur. 13 utvalgte diagnoser. Oslo: Unipub, 2011.

5. Mjåset $\mathrm{C}$. Epilepsi i litteratur og film. Tidsskr Nor Legeforen 2012; 132: 680-3.
6. Böttiger LE. Diktade doktorer: läkaren som litterär gestalt. Stockholm: Läkartidningen, 2000.

7. Ahlzén R. The doctor and the literary text - potentials and pitfalls. Med Health Care Philos 2002: 5: $147-55$.

8. Retterstøl N. Store tanker - urolige sinn. 21 psykiatriske portretter. Oslo: Damm, 2006.

9. Hawkins A. Reconstructing illness. Studies in pathographies. West Lafayette, IN: Purdue Univer sity Press, 1999.

10. Bernhardsson K. Litterära besvär - skildringar av sjukdom i samtida svensk prosa. Lund: Ellerströms, 2010

11. Henriksen N. Om at leve med og håndtere en kræftsykdom: et litteraturstude af danske bogpublicerede kræftfortellinger - med særligt fokus på eksistensielle og æstetiske aspekter. Odense: Institut for Sundhedstjenesteforskning. Syddansk universitet, 2011

12. Meld. St. 47 (2008-2009). Samhandlingsreformen. Rett behandling - på rett sted - til rett tid.

13. Meld. St. 29 (2012-2013). Morgendagens omsorg.

14. Bury M. Health and illness. Cambridge: Polity Press, 2005.

15. Turner B. Medical power and social knowledge. London: Sage Publications, 1995.
16. Frank A. The wounded storyteller. Chicago, IL: The University of Chicago Press, 1995

17. Stensland P. Approaching the locked dialogues of the body - communicating symptoms through illness diaries. Doktoravhandling. Bergen: Univer sitetet i Bergen, 2003.

18. Macnaughton RJ, Evans HM. Medical humanities and medical informatics: an unlikely alliance? Is there a role for patients' voices in the modern case record? Med Humanit 2004; 30: 57-8.

19. Frich JC, Fugelli P. Bør pasienten kunne skrive i egen journal? Tidsskr Nor Lægeforen 2005; 125 918

20. Fugelli P. Journalen. Oslo: Universitetsforlaget, 2013: 252.

21. Beck-Nielsen C. Claus Beck-Nielsen (1963-2001). En biografi. København: Gyldendal, 2003.

22. Knausgård KO. Min kamp 1-6. Oslo: Oktober 2009-2012.

Mottatt 20.2. 2014, første revisjon innsendt 25.4 2014, godkjent 14.5. 2014. Redaktør: Kari Tveito. 